\title{
Horea POENAR
}

\section{Ghostly Articulations: Melancholy and Invention in Nanni Moretti's Palombella Rossa}

\begin{abstract}
In 1989, Nanni Moretti's movie Palombella Rossa is not just another comedy dealing with the key aspect of the times: the end of the Communist regimes. Especially in the context already prepared for the triumphant announcement of post-history and post-ideology, his movie is a profound meditation on what happens to the key communist ideas of equality, solidarity and justice. In our reading of the movie, Moretti reveals the melancholic mechanism of Communist identity and this is done through cinematic means that can still link comic elements to the emergence of short but intense moments of sublime. Our paper rereads Palombella Rossa retroactively as one of the few authentic moments of political thinking of the times (along with Jacques Derrida's Specters of Marx, for example) buried quickly under the new ideology of anticommunism.
\end{abstract}

Keywords: melancholy, commons, figure, Idea, communism.

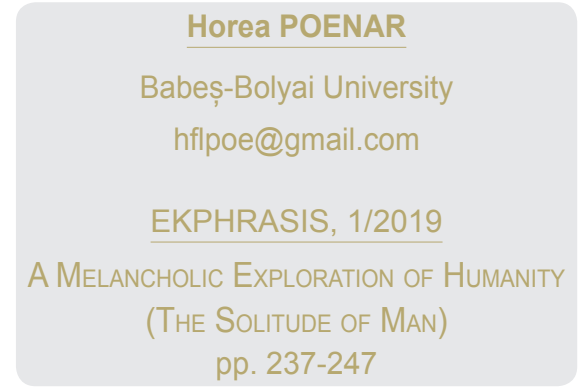

DOI:10.24193/ekphrasis.21.17

Published First Online: 2019/06/27

\section{The Film to Rule All Cinema}

In 1989, the French critic Serge Daney, arguably one of the key thinkers that the history of cinema has produced, wrote in his diary a few notes on Nanni Moretti's Palombella Rossa. He started by exposing the necessity of such a process of notation in this manner: "notes avant que ce film ne devienne à lui seul tout le cinéma" (Daney 1993, 165). At that moment in time and in the understanding of contemporary cinema that Daney was developing, the work of Moretti was positively counterbalancing the recent success of Luc Besson, especially with his 1988 movie Le grand bleu. For the French author, Besson's aesthetics 
was perilously close to the techniques of advertising and was thus contributing to a tendency already visible in (but not only) American cinema to produce "des éléments de base du monde publicitaire" (Daney 1993, 147). In such a context, Palombella Rossa could not only function as a resistance, but, due to the talent and choices of the Italian director, it could concentrate - at least for Daney - the essence of what cinema is and should be. Several points of his demonstration could retain our attention for a while.

Serge Daney pinpoints the importance - in Moretti's cinema - of a cerebral/ mental body that should be distinguished from the traditional burlesque one. It allows viewers to perceive ideas where others would limit their analysis to comic elements. It also permits us to relate Daney's concept to the one later proposed by Fredric Jameson, namely the "narrative body". Studying the paintings of Rubens and Caravaggio (but also the cinema of Buñel), the American critic discovers, in the various postures (that go beyond the demands of figuration and realism and bring into play the plural essence of painting itself) that the history of painting reserves for the body of Christ, the invocation of a "social totality, a collectivity which is in its turn the condition for the closure of the painting as a whole world" (Jameson 2017, 15). According to him, "a narrative body transforms the very nature of narration as such" (Jameson 2017, 20). The process is similar to the one in Palombella Rossa. The body and its figuration, the fact that Michele's body seems to have a continuous necessity to relate to others, and the movie as a whole in its understanding of time (everything happens between two narrative shocks that the central character suffers, the first one producing an acute amnesia, the other one at the end of the movie) - all these elements contribute to a transformation of cinema as such. In Daney's words, this transformation names a "filmage toujours-déjà-démocratique" (Daney 1993, 166). Any hierarchy is refused, as it happens - up to a point - in Fellini, Ferreri or Buñuel, but contrary to them, the characters are not the product of a brain or the puppets manipulated by a puppeteer. They are part of two orders of the real: "deux ordres de réalité: pour-lui et pour-eux. On ne peut plus parler de l'auteur et des fantasmes puisque ses fantasmes sont le résultat d'une situation où il faut être deux pour créer, très éphémèrement, une figure" (Daney 1993, 166). All characters are equal and they collaborate to the creation of figures by relating their body to others: the team, the water, the party or the people. This names and follows an eternal desire (of becoming One or of being part of a collectivity) that has been eternally failing. Cinema (and especially Moretti's cinema) succeeds in offering a (passing) duration to such a desire: "il faut toujours trouver la figure qui fait que, stylistiquement, ça peut durer un peu" (Daney 1993, 166).

Another theoretical similarity is worth pointing here. Jacques Rancière finds in Béla Tarr's cinema an analogical aesthetics. If cinema is defined as the art of the time of the images and sounds, the essence of realism (and it is here that the Hungarian director's style belongs) “c'est la distance prise à l'égard des histoires, de leurs schèmes temporels et de leurs enchaînements de causes et d'effets. Le réalisme oppose 
les situations qui durent aux histoires qui enchaînent et passent à la suite." (Rancière 2011, 13), Béla Tarr - similarly to Moretti - is a philosopher of time because he is first of all a philosopher of cinema. They both provide "des hypothèses plastiques et poétiques" (Daney 1993, 167) that work towards establishing different areas of research for the cinematic experiments. The narrative body always works inside a deconstruction of conventional time. If in the case of Béla Tarr this happens through access to what Rancière defines as le temps d'après - "le temps des événements matériels purs auxquels se mesure la croyance aussi longtemps que la vie la porte" (Rancière 2011, 16) -, Moretti responds to the parenthesis of amnesia through short moments that function as "bombes à fragmentation" (Daney 1993, 167). The difference from the cinema that courts advertisement too closely (as in the case of Besson) is at least triple: the realism of situations that endure is opposed to narratives that simply use time to move on from one situation to another; the narrative (collective) body gives (temporary) life to figures that remain to be explored, analyzed and conceptualized (in a way this is what Gilles Deleuze does in his two volumes on cinema) as opposed to the simplicity of symbols and psychoanalytical forms of decoding (Luc Besson for example constructs his entire Le grand bleu on the simple message to the viewer that the abyss of the sea is that of the unconsiousness); cinema is repositioned as a popular art that implies solidarity and acting: the scene in Palombella Rossa where a mass of people watches Dr Zhivago and encourages the actors as they would encourage sportsmen is clearly opposed to the fetishism of art that in reality refuses its capacity of emancipation. Cinema, in a way similar to sport, is open, it invites taking sides, transforming, acting. In this precise sense, it is not a work of art (which would be perceived as a closed whole and refusing change) but an invitation to be worked, explored and imprinted with (albeit ephemeral) traces.

\section{E tivengo a cercare}

It will not be surprising then that one of the key songs used in Palombella Rossa (and in a key moment, but we will return to that) is a popular hit by Franco Battiato called E ti vengo a cercare. The album on which the song first appears is called Fisiognomica and is one of the Italian hits of 1988. Nanni Moretti uses it in an essential scene. Due to his amnesia, the character he plays in the movie (Michele) has only glimpses of his identity and of his recent past. Two important revelations will take place: that he is a communist and that a few days before, as a member of the Communist Party, he took part in a televised debate on the future and meaning of his party in the new world that is more and more detached from Communist ideas. It is in this scene that, after an attempt to explain why the party is still very much interested in the needs of the people and that it should be understood and followed, Michele bursts into singing. The technique is a well-know Morettian one, already used in his previous movie La messa è finita from 1985. The editing connects the image of Michele singing in front of the camera with the scene in the swimming pool where a game of polo 
takes place. Slowly, everybody in the pool and the entire crowd around it join into singing. The scene - at first comic - changes into a sublime moment of solidarity, especially because it is treated without too much fuss. It is in this context that the lyrics of the song prove to be relevant: "E ti vengo a cercare/ anche solo per vederti o parlare/ perché ho bisogno della tua presenza/ per capire meglio la mia essenza"1. The song turns into a moment of emancipation precisely because it creates the link between the individual (Michele) and the mass of people, a fact that contemporary society thinks that communism can no longer do. It is in fact what the main character searches for during the entire movie.

It is however essential here to make a distinction inside this construction of an identity through solidarity that the song and the movie pretend to enact. Michele's identity (discovered as a revelation that is yet to be comprehended: io sono comunista) remains an empty signifier, and he will search for what it means or has meant (in history and in his life), until the scene we just described where the signifier explodes in its full force. It is here that Palombella Rossa becomes truly innovative and at the same time philosophical: it proves that solidarity and sublime moments of emancipation are still possible under the sign of communism in spite of the reactions and attacks happening around Michele. The distinction we have to make is however between false solidarity and authentic solidarity. The first one is ever-present in the world around us and it is best represented by the Je suis Charlie movement from 2015 that followed the killing spree at the Parisian offices of Charlie Hebdo and especially the socalled march of solidarity with the victims enacted by heads of state on the 11th of January that year. According to Slavoj Žižek, "the first thing to reject is the formula of pathetic identification which only functions within certain limits, beyond which it turns into obscenity" (Žižek 2018, 119). The spectacle of the march of the heads of state was obscene not only because it was staged as a photo opportunity or because it contained dubious characters when it comes to defending press freedom (the case of the Russian Foreign Minister Lavrov or the Israeli Prime Minister Netanyahu), but because it ideologically simplified the world we live in: "the public was offered a sad and depressing choice: you are either (part of the same body as) a flic or (in solidarity with) a terrorist." (Žižek 2018, 122) The solidarity was thus created by portraying a common enemy and obfuscating or even obliterating all other antagonisms and problems within the Western world.

To this false solidarity, an authentic one (created by cinema) can be opposed. There is a scene in Soy Cuba, the 1964 movie by Mikhail Kalatozov, where a group of Cuban revolutionaries is captured by Battista's forces. Their only interest is to find out which amongst them is Fidel Castro. The scene turns into a sublime form of identification through the empty signifier of a leader when each and every one of those arrested proclaims: Yo soy Fidel. The distinction we are exposing here is the one between the pathetic liberal affirmation of solidarity (so as to actually cover and paper through the real absence of it in a society that accepts and even celebrates inequality) and 
the communist solidarity. In this (authentic) second form, the pathos is displaced in two different ways: first, the figure to which one identifies - Fidel - functions as a vanishing mediator, the leader is just a void subject to be filled by the concrete form of the commons, the universality visible only through the singularity of a figure that is not in itself the origin or the point of control. Secondly, Yo soy Fidel functions as a displacement from the discursive affirmation of a common-ity (nowadays mostly reduced to likes on social media and recalibration of profile photos with the colorful message of - for example - Je suis Charlie) to its actual re-enactment: the Cuban revolutionaries, as exposed in Kalatozov's Soy Cuba but also in the earlier movie by Tomás Gutiérrez Alea, Historias de la revolución (1960)², are at the same time all of them and none of them Fidel. This works as true solidarity, and it has to be noticed here that it can only function through the mediation of an identification with such a vanishing mediator: Fidel, or the figure of the communist for Nanni Moretti's character in the movie. In other words, the figure of the universal opening, and not of privileging a certain particular (and already determined with signification) identity as is the case in any false solidarity.

There is however another distinction that needs to be introduced here, one that will prove why Palombella Rossa adds a key element to the problem and even the possibility (in the new world) of solidarity. The difference between Yo soy Fidel and Michele's Io sono comunista is in the melancholic supplement. While Revolution is the incarnation and emergence (not representation) of an Idea or an Event, the times we live in create a distance between the Idea and the present, a constellation that is profoundly melancholic. History, as for example in Lars von Trier's movie Melancholia, is no longer lived in its time, but in its displacement. Palombella Rossa dares to affirm - in a world that is more and more reluctant to such forms of affirmation - that the identity of the subject is in relation to an Idea: Michele understands and accepts that he is a communist. What remains to be seen is what communism means and herein lies the disjunction introduced by time: the communist subject is a profoundly melancholic one.

Jacques Derrida, by following Martin Heidegger (who himself follows Aristotle), observes that for the German philosopher melancholy is the key affect of philosophy. First of all, melancholy is to be distinguished - in spite of their similar nuances from nostalgia: "Melancholy is not nostalgia, but there is between these two affects an affinity, an analogy, that depends at least on the fact that these two sufferings suffer from a lack, a privation, even a bereavement" (Derrida 2011, 111). There are two key elements in Heidegger's thinking on this subject: first the fact that he wants to withdraw melancholy from under the domain of psychology (who can only fail in its understanding) and second that - for him - philosophy is melancholic, fundamentally, "not in its content, but in its form." Derrida goes on to explain what this accent on form means in the philosopher's work: "melancholy affects philosophy insofar as it is creative, a word that we often use wrongly, notes Heidegger, whether speaking of art 
or philosophy. Creative should not be understood here as a privilege or a superiority with respect to other activities, but on the contrary as an extra obligation, a duty that resides in the very creativity. (...) This obligation is, like all duty, the correlative of freedom" (Derrida 2011, 112). Every creative action is thus done in melancholy, which is - this time in Derrida's interpretation which is interested in the difference between what is human and what is animal, how subjectivity works and thus in the phantasm, the specter, the ghostly demarcations that are interior to any concept and to each identity - "the affect of irreparable mourning" (Derrida 2011, 113). It is this lack that is part of an understanding of the subject that cannot function or even exist outside a relation to an alterity. In this sense, Moretti's communist subject is similar to Hayao Miyazaki's portrayal of the antifascist main character from Porco Rosso. Porco is a profoundly melancholic subject who engages against all forms of fascism because of an irreparable mourning: the fact that he is a survivor (of the atrocities of World War I), while all the good ones died there. Porco becomes a living phantom, a subject built on a terrible bereavement that is thus obliged to engage, to fight. His acts are not a privilege or the result of a liberal decision, but a duty, a freedom understood entirely as a form of responsibility. One could invoke here one of Walter Benjamin's theses on the concept of history where he makes this connection between duty and act: the responsibility of the subject is (always) towards those in the past that have fought for justice but have been defeated. Jacques Derrida's frequent revisitation of two lines from the poetry of Paul Celan ("Die Welt ist fort/ Ich muß dich tragen") is related to this point. In Sovereignties in Question. The Poetics of Paul Celan, he connects Freud to the two lines: "According to Freud, mourning consists in carrying the other in the self. Melancholy welcomes the failure and the pathology of this mourning. But if I must (and this is ethics itself) carry the other in me in order to be faithful to him, a certain melancholy must still protest against normal mourning" (Derrida 2005, 160). Melancholy is thus both an ethical necessity and a form of resistance.

\section{The Melancholic Fellowship of an Idea}

The apparent paradox (mainly to obscurantist or liberal minds) is that the only political idea that is ethical appears to be the communist one. The explanation lies in its continuous dislocation. The model of subjectivity contained in Yo soy Fidel gathers all these important details: the communist subject is melancholic due to his essential need for the other and his understanding inside the regulatory (Kantian) horizon of an Idea. This Idea is however a continuous invention, itself dislocated, always at risk and yet always-already there, as the fragile foundation of the subject's freedom. As Slavoj Žižek points out, "universality is not something that should emerge through a long and patient process: it is something that is always-already here as the starting point of every authentic emancipatory process" (Žižek 2018, 226). In a different key, Palombella Rossa makes the same argument. In the scene we have already discussed (in which Franco Battiato's song becomes the new hymn of the communist solidarity) 
the lyrics sung by the crowd point out that "Perché in te vedo le mie radici/ Dovrei cambiare l'oggetto dei miei desideri." This change of the object of desire - because the roots of the subject are in an alterity - exposes the flexibility of the identity and his necessary continuous failure. As melancholic, the subject is always wounded, always disfigured. The desire is not in healing the wound (as mourning can do for Freud), but in the creation of momentary figures. To revisit Daney's idea, the key element in Palombella Rossa is precisely this desire of Michele to create a figure with an other.

The comic situations are perhaps the most suitable to suffer a metamorphosis into sublime (and thus to avoid the pathetic and even pathological recourse to sublime when this is produced precisely by avoiding comedy - and it will not be difficult to identify here the roots of fascism). Nanni Moretti's movie captures like (almost) no other discourse the cynicism of a society that is fast assuming and parading the dogma of anti-communism. We are - let's not forget - in 1989 and the exposure of the new truths of the new world (posthistory, postideology, etc.) is in full view: self-satisfied individuals in the movie are always ready to give lessons, sarcastically, arrogantly and entirely persuaded of their truth. And yet, faced with this fundamental change and the fashions of the new world, Michele cannot escape the grasp of melancholy. Again, if we slightly change the key, it is what Jacques Derrida noticed (and one could even go further and say he performed) in Specters of Marx. Originally a lecture during a conference at the University of California where many participants hurried to do away with Marxism, the French philosopher started his talk by making a dedication. Through it he insisted on what, to him, was the worrying symptom of the new times. Just a few days prior to the lecture an assassination had taken place in South Africa. Chris Hani, a popular hero of the resistance against Apartheid and the leader of the South African Communist Party had been killed. The symptom - for Derrida - lies in the horrifying detail that he was murdered because he was a communist: "I recall that it is a communist as such, a communist as communist, whom a Polish emigrant and his accomplices, all the assassins of Chris Hani, put o death a few days ago, April 10th. The assassins themselves proclaimed that they were out to get a communist" (Derrida 2011, XIV). In a world already quick to portray anything communist as evil and anything anti-communist as desirable, a certain mechanism was at work (and in a way it was starting to be at work, for it would become more and more present in the following decades) that would also allow the attacks on theory itself and the albeit short-lived euphoria of post-theory: a mechanism that Derrida defines through the complex of Marcellus. The reference is of course to Hamlet and Derrida considers that Marcellus' injunction to Horatio - to speak to the ghost and see what it is, what it wants and decide what should be done with it - is exemplary of a certain kind of academic discourse that exalts clear demarcations and completely marginalizes - as non-academic and even as errors of thought - ghostly demarcations: "There has never been a scholar who, as such, does not believe in the sharp distinction between the real and the unreal, the actual and the inactual, the living and the non-living, being 
and non-being" (Derrida 2011, 12). Such a discourse can only refer to communism as and through a closed identity, already decided and thus resolved. Contrary to such a model of thinking (more and more powerful inside academia and the political ideology of liberalism), Derrida's hypothesis in 1993 is that "it will always be a fault not to read and reread and discuss Marx - which is to say also a few others - and to go beyond scholarly 'reading' or 'discussion'. It will be more and more a fault, a failing of theoretical, philosophical, political responsibility" (Derrida 2011, 14). Marxism as Communism have always - and obviously beyond the 'Marxist' ideological apparatuses that were in the process of disappearing after 1989 - functioned in a spectral mode. For every communist, but not only (in fact for every political and even philosophical thinker), Marxism and Communism are an inheritance that should be treated as a coming to terms with a plurality: "One never inherits without coming to terms with some specter, and therefore with more than one specter" (Derrida 2011, 24).

To return to the key in which these problems are presented in Palombella Rossa, Michele exposes exactly this process of coming to terms with his (melancholic) identity of io sono comunista. By accepting this word and thus emerging from the induced amnesia (and we increasingly understand that this amnesia is in fact what affects the (political) world around him), he enters inside the internal dialectic of the communist Idea with its dislocations, irrationality and even illogical mechanism. The movie ends with Michele being caught in one of the paradoxes of this Idea: he tries to deconstruct the central relation between individuality and collectivity that defines the communist axiom of equality: "Siamo uguali, siamo diversi" (We are similar, we are different). The axiom works not by a reduction of differences to a uniform core of the subject, but on the contrary through an access to equality precisely through what makes one singular. The process has been detailed in the recent interpretations of Alain Badiou or Slavoj Žižek ${ }^{3}$ and it is based on the concept of universality defined by Hegel and later reformulated by Marx, but what is essential here is the following detail: equality can only work through a spectral referent, a signifier that represents a void subject (as already observed in the mechanism of Yo soy Fidel). While in Je suis Charlie, my solidarity is to a particular aspect of ideology (the identity of the liberal and multicultural West that functions as a dominant, hegemonic narrative and not as an universal one - in other words the desire is to generalize it, not to universalize it), the solidarity opened by Yo soy Fidel is an open one: it is not to a particular subject - Fidel becomes the horizon of a common work to which in theory everybody could participate. Fidel here is thus not a particular (hegemonic) subject, but an Idea, just as - in Badiou's explanation - the Christian subject for Saint Paul is an open identity that one can be a part of - and herein lies authentic equality - without renouncing his or her particular features (of gender, race, age, ethnicity, etc.). This introduces another twist in the melancholic aspect of the Idea and it virtually displaces it from its Kantian structure (as a regulatory horizon that - to use here the Derridean concept - always remains to come) to the Hegelian understanding: "when we talk about the continuing 
relevance (or irrelevance, for that matter) of the idea of Communism, we should not be thinking of a regulative idea in the Kantian sense but in the strict Hegelian sense for Hegel, 'idea' is a concept which is not a mere Ought (Sollen) but also contains the power of its actualization" (Žižek 2019, 8). And its actualizations do not have to be on a grand scale, but mostly in details, in the plurality of micro-elements that constitute and articulate what could be called a (collective) life.

Nanni Moretti's movies have always paid attention to the problem of the commons, even when - or precisely when - this problem is treated in a comic key. Thus the presence of collective sports in his movies is suggestive first of all of the search for a collective solidarity and energy and secondly of such a spectral referent that one can be a part of without losing his or her differences. Water polo is of course the central example in Palombella Rossa ${ }^{4}$, but one can also recall at least the image of the priest playing football in La messa è finita or the presence of volleyball inside the Vatican in Habemus papam. The same role is played in his movies by pop culture. One essential scene in Palombella Rossa is when the sound of Elvis Presley's I'm on Fire invades the swimming-pool and for a few minutes turns (again $\left.{ }^{5}\right)$ everything into the eerie feeling of sublime: everybody is mesmerized and all the noises, the petty activities are suddenly transformed, sublated (as in Hegel's Aufheben) to a superior level. The main thing to notice here - which also allows us to return to the problem of melancholy - is that such moments/ events do not last. And this is the point where the displacement from Kant to Hegel is justified: moments of solidarity and authentic equality (and thus of communism) do not last, yet they truly exist and are actualizations of the Idea. The rest of time (and history) is lived in melancholy, in its work between absence and repetition. These short moments of solidarity, according to Serge Daney, emerge as "mini-durées, bombes à fragmentation. Mais ces durées ne sont pas, comme chez Godard, des ralentis pour mieux voir ou des 'miracles prolongés de quelques secondes', elles sont des hypothèses plastiques et poétiques, c'est-à-dire qu'elles émiettent l'idée d'une conscience qui s'intensifie toute seule." (Daney 1993, 167). The scene in which everybody (players, public, etc.) approach the TV set to watch - with the awe reserved to religion - and react - as in sport, with encouragement - Dr Zhivago is a perfect example of this necessity for an individual conscience to attain intensity through a third (spectral) element. Franco Battiato's song has a name for it: "Questo sentimento popolare". And then there is, obviously, the water which the movie treats and films like no other. Contrary to Luc Besson's vertical perspective (in tune with the psychoanalytical elements of his movie), Moretti treats the water as a surface that should and is constantly worked and reworked by the body. For Serge Daney it is similar to the surface of the board game Go, but it can also be perceived as a canvas that is constantly remade, repainted, redrawn. It is also similar to the frame of a cinema shot and in many ways the movie can be considered as a degree zero of what cinema is or could be. The relation between aesthetics and politics cannot be reduced to the content of a work or the real-life intentions of a creator. The works of 
Jacques Rancière have clearly shown this: "les images de l'art ne fournissent pas des armes pour les combats. Elles contribuent à dessiner des configurations nouvelles du visibile, du dicible et du pensable, et, par là même, un paysage nouveau du possible" (Rancière 2008, 113). It is not for art (or for an image) to anticipate its effect or to guarantee its signification. The very idea of invention forbids this. In fact, it goes even further: invention, which is always possible precisely as the opening of the possible, is in Derrida's terms what continuously relates the I (and even the we) to the Other: "for the other is always another origin of the world and we are to be invented. And the being of the we, and being itself. Beyond being" (Derrida 2007, 45). When all the good ones are dead (remember the melancholy in Porco Rosso) and the just world they fought for has failed to materialize, what remains to be done is probably to invent ways in which to live with all these specters. Ghostly articulations: another name for the thing we call life.

\section{Endnotes}

1. We can translate it as: "And I come searching for you/ even if it is only for seeing or talking to you/ because I need your presence/ in order to better understand my essence."

2. It is important to note here that both movies are far from any propaganda, being rather a cinema of truth - of course, with the necessary understanding that truth is always ethically engaged. This is also the case of the Soviet cinema of the 1920s which, to liberal eyes, will always appear part of propaganda, due to the inability (or unwillingness) to make the subtle but essential distinction between the thinking of cinema - to be found, as Russian formalists knew it quite early - in form, and the ideas that precede it.

3. The reader should follow the distinction between generalization (a certain particular identity is generalized globally - the mechanism of liberalism and of the Western hegemony imposed everywhere as the correct evolutionary narrative) and universalization (essence exists only as it appears in singular events - the mechanism of Hegelian dialectics).

4. One interesting element is that the child Michele didn't like this sport in which he was forced to be an apprentice to the grown-ups, something that contradicted his emerging and maturing spirit of individualism. The moral is clear: access to equality and freedom can only come through humility and responsibility.

5. This aspect is important: the moments of solidarity (or of collective energy) do not last (one could venture to say that only fascist sublime lasts and thus becomes in fact a pathology), but they repeat through a different form that always requires a surprise, an invention. One could even go further and put it like this: while fascism can be repeated in pretty much the same way (that's why the reading of the similarities between our contemporary world and the Europe of the 1930s are justified) while communism can only return through a different form. This is one more reason why the liberal attempt to treat fascism and communism as two sides of the same coin is wrong and ideologically induced. 


\section{Works Cited}

Daney, Serge. L'exercice a été profitable, Monsieur. P.O.L., 1993.

Derrida, Jacques. Inventions of the Other. Stanford University Press, 2007.

Derrida, Jacques, et al. Sovereignties in Question: the Poetics of Paul Celan. Fordham University Press, 2005.

Derrida, Jacques, and Peggy Kamuf. Specters of Marx: the State of the Debt, the Work of Mourning, and the New International. Routledge, 2011.

Derrida, Jacques. The Beast and the Sovereign. University of Chicago Press, 2011.

Jameson, Fredric. The Ancients and the Postmoderns. Verso, 2017.

Rancière, Jacques. Béla Tarr, le temps d'après. Capricci, 2011.

Rancière, Jacques. Le spectateur émancipé. La Fabrique, 2008.

Žižek, Slavoj. Like a Thief in Broad Daylight: Power in the Era of Post-Humanity. Penguin Books, 2019.

Žižek, Slavoj. The Courage of Hopelessness: Chronicles of a Year of Acting Dangerously. Penguin Books, 2018. 